\title{
Analysis of economic capacity utilization in the Nigerian sugar industry (1970 - 2010)
}

\author{
Sunday B. Akpan ${ }^{1 \star}$, Inimfon V. Patrick ${ }^{1}$, Daniel E. John ${ }^{2}$ and Samuel J. Udoka ${ }^{1}$ \\ ${ }^{1}$ Department of Agricultural Economics and Resources Management, Akwa Ibom State University, Ikot Akpaden, Mkpat \\ Enin, Akwa lbom State, Nigeria. \\ ${ }^{2}$ Department of Agricultural Economics and Extension, University of Uyo, Akwa lbom State, Nigeria.
}

Accepted 14 May, 2013

\begin{abstract}
The study analyzed economic capacity utilization rates in the sugar industry for the period 1970 to 2010 in Nigeria. Secondary data obtained from sugar firms; Central Bank of Nigeria; National Bureau of Statistics and the Federal Ministry of Finance were used in the study. Stochastic Cobb-Douglas cost functions for the sugar industry were estimated from which indices of economic capacity utilization rates were obtained. Trend in the economic capacity utilization rate showed undulated pattern with an average index of $60.30 \%$ and excess economic capacity of $39.70 \%$. Multiple-regression of various forms based on the ordinary least squares technique was used to determine factors that influence the performance indicators in the industry. Empirical results revealed that economic capacity utilization rates in the sugar industry was influenced by the inflation rate, per capita real GDP, energy consumption of the industry, federal government expenditure on the sugar industry and the period of liberalization. The result of the regression and descriptive analyses revealed that the sugar industry in Nigeria was constrained by insufficient production inputs. Policy measures aimed at reduction or maintaining a steady or less fluctuated inflation rate in the country, expansionary aggregate demand, increase funding to agencies that have direct dealings with the sugar production and adequate provision of electricity to the industry as well as the adoption of the liberalization industrial policy on sugar industry were recommended.
\end{abstract}

Key word: Sugar, industry, capacity, utilization, economic, Nigeria.

\section{INTRODUCTION}

The sugar sub-sector has contributed to the development of the Nigeria's economy (NSDC, 2010). The importance of the sub-sector is derived from its contribution to the employment, development of other subsidiary industries and food self sufficiency as well as its significant impact on the rural economy (Nwaobi, 2005; ADB, 2000; ADF, 2000). In Nigeria, the demand for household sugar consumption remains firm, the soft drink production alone accounts for about half of the total industrial sugar usage in Nigeria (Michael, 2010). The domestic consumption of sugar in Nigeria is in excess of one million tons per annum. Domestic production of sugar in the country had suffered considerably in the past years. For instance, the domestic output declined from 51,080 tonnes in the period 1988 to 1990 to 5,597 tonnes in the period 2001 to 2003 (Wada et al., 2001; Olomola, 2007 and SSC, 2010 (Table 1). Currently, domestic production of sugar is slightly less than $5 \%$ of the country's annual requirement (CBN, 2008; NSDC, 2012).

Data in Table 1 reveals that from 2000 to 2003, the domestic sugar production declined significantly reaching all time low value of less than $1.00 \%$ of domestic sugar consumption in the country. The dismal performance of the sub-sector had been attributed to diverse factors 
Table 1. Sugar supply and import price of sugar in Nigeria (1970 to 2008).

\begin{tabular}{ccccccc}
\hline Year & $\begin{array}{c}\text { Average } \\
\text { domestic } \\
\text { output (tons) }\end{array}$ & $\begin{array}{c}\text { Average } \\
\text { import } \\
\text { (tons) }\end{array}$ & $\begin{array}{c}\text { Average } \\
\text { total supply } \\
\text { (tons) }\end{array}$ & $\begin{array}{c}\text { Average } \\
\text { Import Price } \\
\text { N/ton }\end{array}$ & $\begin{array}{c}\text { Share of } \\
\text { domestic to total } \\
\text { output (\%) }\end{array}$ & $\begin{array}{c}\text { Share of } \\
\text { import to total } \\
\text { output (\%) }\end{array}$ \\
\hline $1970-1972$ & 38141 & 114158 & 152299 & 144.4 & 33.41 & 66.59 \\
$1973-1975$ & 42594 & 99335 & 141929 & 424.6 & 30.01 & 69.99 \\
$1976-1978$ & 34074 & 327382 & 361458 & 332.6 & 9.43 & 90.57 \\
$1979-1981$ & 36296 & 632379 & 668675 & 349.8 & 5.43 & 94.57 \\
$1982-1984$ & 37778 & 571562 & 609340 & 293.7 & 6.20 & 93.80 \\
$1985-1987$ & 51872 & 450130 & 502002 & 465.2 & 10.33 & 89.67 \\
$1988-1990$ & 51080 & 292766 & 343846 & 1878.5 & 14.86 & 85.14 \\
$1991-1993$ & 40735 & 485540 & 526275 & 6681.5 & 7.74 & 92.26 \\
$1994-1996$ & 45577 & 390718 & 436295 & 7696.6 & 10.45 & 89.55 \\
$1997-2000$ & 13654 & 729870 & 743524 & 10980 & 1.84 & 98.16 \\
$2001-2003$ & 5597 & 903066 & 908663 & 25229 & 0.62 & 99.38 \\
$2004-2008$ & 11194 & 350113 & 361307 & 42625 & 3.20 & 96.80 \\
\hline
\end{tabular}

Sources: National Sugar Company Document (NISUCO) (1999, 2000); Savannah Sugar Company limited (SSC) (2000), and FAO database (2011).

including economic, environmental, social, technology and factory based hindrances (Lafiagi, 1984; Wada et al., 2001; Akpan et al., 2011, 2012a, 2012b).

The two major integrated sugar plants at Bacita in Kwara state (Nigerian Sugar Company) and Numan in Adamawa state (Savannah Sugar Company) were established in 1961 and 1977, respectively, following the adoption of import substitution industrialization policy in the country (ISYB, 1978). The aims were to encourage technological development, reduce the volume of imports and encourage foreign exchange savings by producing locally some of the imported consumer goods (Ayeni, 1981; Ekeocha, 2009). The two sugar plants had a combined installed capacity of 105,000 tonnes per annum or less than $10 \%$ of the country's annual requirement (FMI, 2003). Due to some rather complex factors, the major existing sugar companies at Bacita and Numan whose combined installed capacity was expected to climb to 165,000 tons per annum after their expansion programme initiated by the federal government in collaboration with the African Development Bank and African Development Fund in 1989 and 1991, respectively could not fulfill the sub-sector expectations. Besides, the two major sugar producing companies, the other 2 mini sugar firms at Sunti (Niger State) and Lafiagi (Kwara State) were producing relatively small quantities of Sugar (i.e. less than 1,000 tons per annum each) (Wada et al., 2001; Nwaobi 2005; NSDC, 2006).

The general performance of the sugar sub-sector was fair in the early 1970 s as indicated in Table 2 . During this period, the sugar industry had fully integrated its operations backward through its direct involvement in sugarcane farming and sourcing of other raw materials locally (Ayayi, 1988; Akpan et al., 2012a). Towards the middle of 1980s and the late 1990s, the performance of the sub sector started to decline. The index of sugar production declined from $117.8 \%$ in the period 1986 to 1990 to $47.7 \%$ in 2001 to 2005 periods. By the middle of 1980 's, the country's foreign exchange earnings declined significantly arising from the oil glut. The high import dependence manufacturing sector in the country became a serious liability on the economy (Isola, 2006).

The prevailing economic environment and the industrial policies during 1970 s to early 1980 s favored an average capacity utilization rate of above $50 \%$ in the sugar cocoa confectionery sub-sector (CBN, 2006; MAN, 2006). As revealed in Table 3 , the agro based industries generally witnessed decline in productivity during the structural adjustment programme (SAP) period. The average technology based capacity utilization rate of the sugar cocoa confectionery industry stood at $40 \%$ in 1986 and declined to $36 \%$ during the early structural adjustment programme (SAP) period. The instability in some macroeconomic variables in the Nigerian economy and agrobased firm related constraints during the SAP period probably contributed to the decline in the productivity of the sugar industry. The decline in the sub sector productivity might have manifested through the influence of rising inflation rate, low external reserves which constrained importation of sugar industry's equipment, deteriorating value of naira as well as demand and other production constraints imposed by low real GDP per capita during the period ((Isola, 2006; Akpan et al., 2012b).

In the early 1990s, the Nigerian sugar sub-sector was still largely underdeveloped with untapped resources and potentialities. The 4 existing companies were completely government owned and were characterized by low productivity occasioned by managerial, financial and infrastructural and technological constraints. The awfully low production by the existing sugar companies could only satisfy about $5 \%$ of the nation's requirement and the 
Table 2. Average index of agro-based manufacturing sub-sectors in Nigeria $(1985=100)$

\begin{tabular}{lccccccc}
\hline Agro-based Industry & $\mathbf{1 9 7 0 - 1 9 7 5}$ & $\mathbf{1 9 7 6 - 1 9 8 0}$ & $\mathbf{1 9 8 1 - 1 9 8 5}$ & $\mathbf{1 9 8 6 - 1 9 9 0}$ & $\mathbf{1 9 9 1 - 1 9 9 5}$ & $\mathbf{1 9 9 6 - 2 0 0 0}$ & $\mathbf{2 0 0 1 - 2 0 0 5}$ \\
\hline Sugar & 420.3 & 534.3 & 149.6 & 117.8 & 101.2 & 56.4 & 47.7 \\
Textiles & 110.6 & 171.4 & 100.9 & 100.8 & 117.2 & 97.4 \\
Foot work & 253.6 & 255.9 & 111.1 & 62.1 & 73.7 & 47.7 & -1 \\
Total GR & 24.8 & 80.5 & -169.7 & -65.5 & 20.9 & -58.9 & -24.4 \\
Ave.GR. (\%) & 8.3 & 26.8 & -56.6 & -21.8 & 7.0 & -19.6 \\
\hline
\end{tabular}

Source: Computed by using data from CBN statistical bulletin (2006).

Table 3. Economic and Industrial Sector Performance in Industrial Policy Regimes in Nigeria.

\begin{tabular}{|c|c|c|c|c|c|c|c|c|}
\hline \multirow[t]{2}{*}{ Indicator } & \multicolumn{3}{|c|}{ Import Substitution Era } & \multicolumn{5}{|c|}{ Liberalization Era } \\
\hline & $1970-1975$ & 1976-1980 & 1981-1985 & 1986-1990 & 1991-1995 & $1996-2000$ & 2001-2005 & 2006-2010 \\
\hline \multicolumn{9}{|l|}{ Mean macroeconomic variable indicator } \\
\hline Inflation rate (\%) & 14.3 & 13.0 & 19.4 & 20.5 & 48.9 & 12.3 & 15.7 & 9.65 \\
\hline Official exchange rate $(\mathbb{A} / \$)$ & 0.66 & 0.69 & 0.77 & 5.90 & 19.16 & 54.78 & 127.84 & 134.08 \\
\hline External reserve $(\mathrm{Ab})$ & 1.19 & 3.06 & 1.40 & 11.98 & 39.2 & 361.6 & 1869. 7 & 6366.194 \\
\hline Index of energy consumption $(1985=100)$ & 26.3 & 64.6 & 122.8 & 95.6 & 95.7 & 83.3 & 167.4 & NA \\
\hline Real GDP per capita ( $A$ / person) $(1985=100)$ & 177.2 & 735 & 3.25 & 962 & 674 & 547 & 819 & 4562.63 \\
\hline $\begin{array}{l}\text { Real foreign private investment in Manu and } \\
\text { processing }(\mathrm{Ab})\end{array}$ & 2.79 & 3.17 & 2.74 & 2.20 & 1.53 & 1.09 & 1.26 & NA \\
\hline Index of agricultural production $(1990=100)$ & 65.62 & 56.44 & 58.74 & 79.20 & 121.6 & 141.5 & 158.2 & NA \\
\hline Index of manufacturing production $(1985=100)$ & 32.85 & 75.42 & 105.7 & 135.4 & 154.7 & 137.2 & 145.6 & NA \\
\hline \multicolumn{9}{|l|}{$\begin{array}{l}\text { Mean agro based industry capacity utilization rate } \\
(\%)\end{array}$} \\
\hline Meat and dairy product & NA & NA & 55.85 & 30.07 & 30.34 & 36.46 & 63.12 & 461.01 \\
\hline Vegetable and grains mill & NA & 92.37 & 48.97 & 33.40 & 35.54 & 18.34 & 51.18 & 48.74 \\
\hline Bakery product & 66.4 & 71.48 & 58.64 & 37.90 & 37.90 & 21.45 & 58.23 & 62.11 \\
\hline Sugar cocoa confectionery & NA & 59.59 & 53.12 & 42.20 & 33.12 & 31.42 & 31.32 & 59.00 \\
\hline Textile & 79.7 & 80.72 & 59.84 & 51.20 & 48.34 & 34.30 & 42.61 & 59.66 \\
\hline Leather products & 77.2 & 75.08 & 54.50 & 45.00 & 42.38 & 37.78 & 45.38 & 50.50 \\
\hline Tyres and tube & NA & NA & 42.58 & 53.04 & 41.70 & 30.80 & 42.62 & 49.75 \\
\hline Leather foot wear & NA & 47.5 & 76.69 & 55.56 & 41.18 & 24.57 & 26.0 & 74.99 \\
\hline Average agro industry capacity utilization rate (\%) & 75.10 & 73.72 & 56.12 & 43.10 & 38.46 & 28.01 & 47.4 & 51.70 \\
\hline Average industry capacity utilization rate (\%) & 76.6 & 71.12 & 53.58 & 41.14 & 35.40 & 33.59 & 46.18 & 41.68 \\
\hline
\end{tabular}

Source: Computed by using data from Central Bank Nigeria Statistical Bulletin (2006) and World Bank Reports (20021). NA means data not available. 
wide gap between sugar demand and supply was filled through importation with huge amount of foreign exchange requirement. With the dwindling fortune of the federal government resources, the existing sugar companies were wallowed in low productivity due to inadequate finance for both recurrent and capital expenditure (FMI, 2003). This situation further deepened the fortune of the local sugar production since all sugar companies were government owned. In an attempt to accelerate the domestic sugar production, the National Sugar Development Council (NSDC) was established by decree 88 of 1993. The NSDC was mandated to develop strategies that would promote the local production of sugar such that $70 \%$ of the country's sugar requirement would be met by domestic production (Busari et al., 1996 and FMI, 2003). Based on the government policy of direct participation and investment in the sugar industry, NSDC strategies were the expansion and rehabilitation of the 4 government owned sugar industries, establishment of 5 medium scale and many mini sugar plants in the country as well as the establishment of the sugarcane Research Development and Training Center. The Council however recorded some successes in implementing some of its strategies but could not still upsurge local production of sugar in the country (FMI, 2003).

Following the government reform programme on privatization and commercialization between 2001 and till date; the 2 integrated sugar companies and 2 mini sugar plants in Nigeria were partially privatized. The aims were to promote efficiency in resource utilization, increase productive capacity and increase the role of the private sector in the sugar industry (Zayyad, 2007). Despite this lofty attempt by the government to strengthen the productive capacity of the sugar sub-sector, the productivity of the sub-sector continued to decline. The average index of production in the sugar industry was $17.9 \%$ in the period 1970 to 2005 (CBN, 2006). During the post Structural Adjustment Programme era, growth in the sugar industry in Nigeria was hindered due to increase in manufacturing cost (Ogunbayo, 2009). The average capacity utilization for the sugar cocoa confectionery sub sector during post SAP period as published by official sources in Nigeria was below $30 \%$ (MAN, 2009; CBN, 2009).

\section{Problem statement, objectives and justification of the study}

Capacity utilization has an important bearing on the financial performance of any firm and the entire industry. It is widely used in business cycle analysis to characterize the situation of individual industry or the whole economy and to assess the appropriateness of the economic policy (Danish, 2003). The Nigerian monetary policy, among other things, aims at achieving full employment of resources without inflation (Anyanwu et al., 1997). Consequently, over the years the government has employed a number of monetary policy measures to increase capacity utilization in the economy and at the same time curb inflation. Government policy measures have varied from the pre-structural Adjustment Programme (Pre-SAP) period (1970 to 1985) to the SAP (1986 to 1993) and post-SAP (1994 to date) periods. Direct monetary control techniques were employed during the pre-SAP period. The major tools of monetary policy were administered interest and exchange rates, special deposits by banks, prescription of cash reserve requirements, selective credit controls and credit ceilings (Anyanwu et al., 1997).

In the SAP period (1986 to 1993), indirect measures were used to control the ability of banks to extend new credits alongside credit ceilings. The measures included the deregulation of interest rates, increase in commercial banks cash reserve requirements and its extension beyond demand deposits to include time and savings deposits. Other measures were the mopping of banks' excess liquidity through the issuance of stabilization securities and the transfer of public sector accounts from banks to the Central Bank of Nigeria (CBN). On June 30, 1993, the CBN formally introduced its open market operations (OMO). In the post-SAP period (1994 to date), administratively controlled measures were first adopted in1994 and were abandoned in 1995 for policy of guided deregulation. Banks became directly involved in equity funding and management of small-scale enterprises. Apart from monetary policies, the government also employed some fiscal policy measures to ensure full employment of resources. These measures include tax holidays, tariff protection, import duty relief, bans on imports and the provision of credit facilities.

In the sugar industry, some specific policies employed over the years to boost sugar production in the country included $50 \%$ tariff on the importation of white sugar, $5 \%$ levy on imported raw sugar, free excise duties on sugar production, reduction of import duties on sugar industry machineries, 5-year tax holiday to sugar refineries and privatization of the major sugar firms in the country, as well as, the sugar expansion programme in collaboration with the African Development Bank (ADB) and African Development Fund (ADF), 1989 and 1991 respectively. These measures were meant to stimulate the local production and hence increase the productivity and capacity utilization in the sub-sector. In spite of these measures, Nigeria still imports more than $90 \%$ of its sugar. Nigeria is the largest consumer of sugar in the West African sub-region and second in Africa (ADB and ADF, 2000). The country also has a large area of cultivable land, suitable for the growing of industrial sugarcane (Busari et al., 1996). Despite the favorable agro-climatic and edaphic conditions for the production of sugar-cane in addition to the long period of existence of sugar mills; sugar requirements of the country remain largely unmet from domestic sources (Olomola, 2007). 
The domestic sugar production has oscillated between 7,000 tonnes and 55,000 tonnes per annum from 1969 to 2010 (Wada et al., 2001; SSC, 2010).

In Nigeria, the issue on industry's economic capacity utilization rate is relatively new compared to other methods of capacity utilization especially in the agrobased industries. Several authors in Nigeria have worked on technology based capacity utilization in many industries (Fabayo, 1981; Ukoha, 2000; Soderbom et al., 2002; Salimonu et al., 2006; Adeel et al., 2006; Raimi et al., 2009; Akpan et al., 2011, 2012b). Most studies on the concept were based on survey opinions of firms on capacity utilization rate rather than empirical estimation in the individual industry through optimization of the industry's resource endowment (Soderbom et al., 2002; Adeel et al., 2006). Other studies based their analyses on the data published by the official sources such as Central Bank of Nigeria (CBN) and Manufacturing Association of Nigeria (MAN) with no consideration on capacity utilization estimation procedures (Fabayo, 1981; Ukoha, 2000; Salimonu et al., 2006 and Raimi et al., 2009). Data on capacity utilization rates in the sugar-cocoa confectionary sub-sector, as reported by independent official sources showed that capacity utilization rates declined from an all time high value of $85 \%$ in 1975 to $50 \%$ in 1983 , and remained consistently below $50 \%$ from 1983 . This study investigated whether the sugar industry is really operating at half capacity in the sense that firms could double output without experiencing a rise in average costs.

Therefore, this study differs from the previous ones conducted in Nigeria as it estimated the economic capacity utilization rates for the sugar industry using the sugar industry production and cost data. In addition, it analyzed the factors which influence economic capacity utilization in the industry. Hence, the result of the study is a reliable quantitative fact and source of reference to policy makers to efficiently make relevant policies that can promote the sugar industry's performance in Nigeria. In addition, the results would serve as a useful screen board for future analysis of capacity utilization in any sector of the economy. Furthermore, this study provided a frame of reference for agricultural economists, economists, manufacturers, planners and students who might be carrying out studies on capacity utilization.

\section{The concept of economic capacity}

The earliest work on the economic concept of firm's capacity is that of Cassels (1937). The economic capacity takes explicit account of economic factors like cost, price, revenue and profit. It is defined as the optimum output of a firm from economic point of view. This approach considers capital as a quasi-fixed input, and allows for distinction between short and long-run cost curves. In the long-run, capacity can be adjusted in order to achieve optimal output (cost-minimizing, profit-maximizing) level. In the short-run, capital is fixed and only the variable inputs can be varied. Hickman (1964) defined economic capacity of a firm as that output level at which the short run average total cost curve is at its minimum; while Klein (1960) and Friedman (1963) defined economic capacity as the output level at which the long-run and short-run average total cost curves are tangent.

The relationship between the 2 notions of economic capacity measures depends upon the degree of scale of economies of a firm. Berndt and Hesse (1986) advocated that, under the assumption of prevailing constant returns to scale in the long-run, the tangency point between the long run and short-run average total cost curves will coincide at a point where the long-run and the short run average total cost curves reach their minimum. Hence, the two economic measures of capacity would be equivalent. The first two measures of economic capacity are termed primal economic capacity because they are directly measured in physical output and expressed in physical unit. The third measure of economic capacity proposed by Berndt and Morrison (1981), and Morrison (1985) is considered a dual-based concept and thus defines economic capacity in terms of firm's cost. They define economic capacity as corresponding to the shadow total cost of a firm. The shadow total cost is defined as the cost of the variable inputs plus the shadow cost of quasi-fixed inputs.

\section{LITERATURE REVIEW}

Optimizing economic variables of firms to derive economic capacity and utilization is relatively new in the literature especially in the sub-Saharan African countries. Berndt and Morrison (1981) used quadratic cost function to estimate capacity utilization rates for the U.S. manufacturing sector over the period 1958 to 1977 . The model consisted of 3 variable factors, energy, materials and production workers as well as 2 quasi-fixed factors, capital and non production workers. He discovered capacity utilization rates greater than unity for the entire period. He also applied the same methodology to the U.S.A. automobile industry and obtained capacity utilization rates that exceeded unity for the years considered. While studying the performance of the Irish manufacturing sector, Kenny (1996) applied the translog Cost Function Approach on data from the manufacturing sector and under the assumption of long-run constant return to scale to estimate economic capacity utilization rates for the sector. In recognition of the dichotomy that characterized Irish industry, the model was fitted to 2 individual sub-sector classification; the hi-technology and traditional manufacturing sub sectors. The results revealed that substantial degree of excess capacity existed in the sector during the period 1970 to 1990. The traditional industrial sub-sector had a significant excess capacity compared to the hi-technology sub-sector. World Barik (2000) estimated the economic rate of capacity for the Indian paper industry for the period 1973 to 1974 and 
1997 to 1998 using the translog Variable Cost Function. $\mathrm{He}$ found that under utilization of economic capacity prevailed in the industry, and also a decline in the rates of capacity utilization over time. Prior and Nelda (2001) in their study, estimated capacity utilization rate and cost efficiency in the chemical industry in Romania between period 1996 and 1997. They employed Cost Efficiency Data Envelopment Analysis (DEA) methodology. The result obtained showed high inefficiency and low capacity utilization rates among the industries. Hashim (2003) studied the trend in economic capacity utilization rates in Indian airlines for the period 1964 to 1990 . He used the translog cost function to estimate the economic capacity utilization rates across the periods. The estimation of economic capacity utilization rates was based on 2 alternative measures of economic output. The first was where the short-run average cost was minimum, and the second was where the short-run and long-run average cost curves were equal. The results reveal an average estimated economic capacity utilization rate of 0.32 and 0.37 for the two methods respectively.

The results further showed that economic capacity utilization rates for the Indian airlines was generally poor, showing downward trend pattern in the study period. Lecraw (1978) analyzed factors that influence economic capacity utilization of 200 manufacturing firms in Thailand during the period 1962 to1974. He estimated profitmaximizing capacity utilization rate for each firm by using the projected balance sheets and income statements that the firms had prepared at the time of their initial investment. Their 'optimal' rate was roughly twice the rates chosen by the firms. The extent of non-optimal capacity underutilization of a firm was determined by the nationality of the firm's owner, entry date, number of firms in the industry, projected profits, and the manager's perceived risk of multi-shift operations. Dunlevy (1980) and Hayes and stone (1983) in their independent investigations in U.S.A found a significant positive relationship between capacity utilization rates in the industrial sector and the country's exports.

McElthattan (1985) investigated the relationship between capacity utilization rate in the industrial sector and inflation rate in U.S.A. She obtained a significant and positive relationship between the two variables. She however inferred from her regression results that for each percentage point, all industries capacity utilization rate exceeded $82 \%$, inflation rate would accelerate by about 0.15\% points. Earlier, Franz and Gordon (1993) discovered that capacity utilization rate depends more on inflation than on unemployment in both U.S.A and Germany economies. They also confirmed the nonaccelerating inflation rate at capacity utilization rate for the U.S.A of about $82 \%$, using Federal Reserve Bank Measures. Similar results were obtained by Garner (1994) and Yoo (1995). Gokcekus (1997) tested the hypothesis that trade liberalization increases economic capacity utilization in Turkish rubber industry. Using Generalized Leontief cost function, he established a positive relationship between the 2 variables. Seth (1998) established a positive link between industrial capacity utilization rates in India and public investment in infrastructures, capital, intermediary import and adoption of liberal policy. Kim (1999) analyzed the determinants of economic capacity utilization in U.S.A manufacturing sector. Evidence showed that capital stock, price of materials, capital price have significant negative relationship with the economic capacity utilization rates; while energy price, labour price and output have significant positive influence on the economic capacity utilization rate in the manufacturing sector. In India, Azeez (2002) investigated the impact of Indian industrial reform policies on the economic capacity utilization rate of the industrial sector. He discovered three distinct phases relating to economic capacity utilization rate movement during the policy era. Phase 1 (1974 to 1984) was characterized by relatively wide fluctuations; phase 2 (1985 to 1990) witnessed relatively stable fluctuation, while phase 3 (1991-1998) exhibited the characteristics of the phase 1. According to him the impact of the industrial reform on the industries economic capacity utilization rate was not remarkable. Kumar et al., (2009) used time series data from the period 1974 to 2005 to analyze the trends in the capacity utilization rates in the sugar industry in India. The result revealed that, the industry was operating with an excess capacity of $13 \%$ in each of the study year. The result also showed that, capacity utilization declined during the post reform years, and that the availability of raw materials was the most significant variable explaining the variation in the capacity utilization rate in India's sugar industry.

In Nigeria, Adeel et al. (2006) employed the survey and expert opinion approach to estimate capacity utilization rate among Nigerian firms. They discovered that firm's capacity utilization rates were affected by erratic power supply, variations in demand, insufficient capital and insufficient imports and domestic raw materials. Ukoha (2000) studied the determinants of the manufacturing capacity utilization rate in Nigeria in the period 1970 to 1988. He employed OLS method on secondary data published by the Central Bank of Nigeria. The result revealed that, the real exchange rate, federal government capital expenditure on the manufacturing sector and the per capita real income had positive effects on the manufacturing capacity utilization rate. On the other hand, the inflation rate and the real loans and advances to the manufacturing sector had negative effects on the capacity utilization rate of the sector. Akpan et al. (2011) investigated the influence of firm related factors and industrial policy regime on technology based capacity utilization in sugar industry in Nigeria. The empirical result reveals that sugar cane price and sugar industry's real energy consumption have significant negative relationship with the technology based capacity utilization in the sugar industry in Nigeria. On the other hand, the wage rate of skill workers, industry's, real research expenditure, human capital and period of import 
substitution have significant positive influenced on the technology based capacity utilization rate in the industry Akpan et al. (2012a) established the empirical relationship among technical efficiency, macroeconomic variables and industrial policy regimes in the Nigeria's sugar industry. Their result revealed that technical efficiency was influenced by the industrial sales growth, capital-labour ratio, official tariff rate on sugar import, real exchange rate and the content of the liberalization policy period. Akpan et al. (2012b) also analyzed the impact of macro-economic variable fluctuation on technology based capacity utilization in the sugar industry in Nigeria. The empirical results showed that the real sugar import, exchange rate, import price of sugar, parallel market exchange rate premium and tariff rate on sugar import were significant variables that influenced technology based capacity utilization rate in the industry.

\section{THEORETICAL FRAMEWORK} Measuring economic capacity and capacity utilization
rates using stochastic cost efficiency frontier (ECUR)

Following the fundamental assumption that capacity utilization rate is a short-run concept, and that variable inputs are efficiently utilized given the constraints imposed by quasi-fixed factors; the original efficiency stochastic cost frontier (SCF) was modified to represent economic efficiency capacity utilization rate (EECUR) by incorporating only the quasi-fixed factors into the firm's cost function (FAO, 2006). This implies that frontier cost is determined by efficient use of quasi-fixed input prices.

$\operatorname{EECUR}_{t}=\frac{C_{j}^{*}}{C_{j}}=\frac{f\left(X^{*} ; \beta\right) \exp \left(V_{j}\right)}{f\left(X^{*} ; \beta\right) \exp \left(V_{j}-U_{j}\right)}=\frac{1}{\exp \left(-U_{j}\right)}$

Where $C^{*}$ is the minimum or the frontier cost and $C_{j}$ is the actual cost of production. $\mathrm{X}_{\mathrm{j}}^{*}$ is the price of quasifixed inputs of j's firm. Economic efficiency capacity utilization rate (EECUR) is a biased index because it incorporates both capacity utilization and economic efficiency of fixed inputs. Unbiased economic capacity utilization rate (ECUR) was derived by dividing the index of economic efficiency capacity utilization rate (EECUR) by the cost efficiency score estimated in the traditional manner, such that;

$E C U R_{t}=\frac{E E C U R_{t}}{E E_{t}}$

Where EE is the cost efficiency score computed for all factors of production. Firm's economic capacity is estimated as thus;

Economic Capacity $=\frac{\text { Actual } T V C_{t}}{\text { ECUR }_{t}}$
Hence, a firm that has full economic capacity utilization rate operates on the cost efficiency frontier $(E C U R=1)$, while those with economic capacity utilization rate less than unity (that is, ECUR < 1) operate below the cost efficiency frontier. This implies that the firm's fixed inputs are under-utilized and investment disincentive exists on the fixed factors of such firm. When economic capacity utilization rate is greater than unity (that is, ECUR $>1$ ), it implies that fixed inputs are over utilized and there is high tendency of investment incentive on the fixed factors of production (Morrison, 1985).

\section{Klein capital utilization model}

The relationship between capacity utilization rate of a firm and exogenous factors is found in Klein and Preston (1967) capital utilization model. In the model, they assume that;

$\left\{\frac{K_{t}^{f}}{K_{t}}\right\}=\left\{\frac{L_{t}^{f}}{L_{t}}\right\}$

Where, $K_{t}^{f}$ and $L_{t}^{f}$ are desired capital and manpower levels, while $K_{t}$ and $L_{t}$ are actual level of capital and manpower respectively. They also relate firm's output gap to manpower change as thus;

$\left\{\frac{Y_{t}}{Y_{t}^{f}}\right\}=\left\{\frac{L_{t}^{f}}{L_{t}}\right\}$

Where $Y_{t}$ is the actual output and $Y_{t}^{t}$ is the full employment level of output.

Combining Equation (4) and (5)

$\left\{\frac{Y_{t}}{Y_{t}^{f}}\right\}=f\left[\left(\frac{K_{t}^{f}}{K_{t}}\right),\left(\frac{L_{t}^{f}}{L_{t}}\right)\right]$

Where the firm output gap, $\left\{\frac{Y_{\varepsilon}}{V_{t}^{f}}\right\}$ represents the capacity utilization rate at period " $\mathrm{t}$ " (Klein and Preston, 1967; Johansen, 1968). Attaching log to both side of the equations and assuming Cobb- Douglas production function;

$\operatorname{Ln} Y_{t}-\operatorname{Ln} Y_{t}^{f}=\operatorname{Ln} A_{0}+\operatorname{Ln}\left(K_{t}^{f} / K_{t}\right)^{\alpha}+\operatorname{Ln}\left(L_{t}^{f} / L_{t}\right)^{\beta}+\operatorname{Ln} Z_{t}$

Following the flexible investment function;

$I_{t}=\delta\left(K^{*}-K_{t-1}\right.$

Where $\mathrm{K}^{*}$ is the desired capital stock. Then 
$K^{*}=K_{t}^{f}=\delta^{-1}\left(I_{t}-K_{t-1}\right)$

Substituting Equation (8) into (7) will produce;

$\operatorname{Ln} Y_{t}-\operatorname{Ln} Y_{t}^{f}=\operatorname{Ln} A_{0}+\operatorname{Ln}\left[\delta^{-1}\left(I_{t}-k_{t-1}\right) K_{t}^{-1}\right]^{\alpha}+\operatorname{Ln}\left(L_{t}^{f} / L_{t}\right)^{\beta}+\operatorname{Ln} Z_{t}$

Also, firm's demand for labour depends on the real wage rate in the economy. Hence at full employment level, wage rate corresponds to $\left(\mathrm{W} / \mathrm{P}_{0}\right)$, while $\left(\mathrm{W} / \mathrm{P}_{1}\right)$ corresponds to wage rates below equilibrium level. Thus;

$\left\{\frac{L_{t}^{f}}{L_{t}}\right\}=\frac{\left(W / P_{0}\right)}{\left(w / P_{1}\right)}$

Where "W" is the labour wage and "P" is the general price level in the economy. Substituting Equation (10) into (9) produces;

$$
\begin{aligned}
& \operatorname{Ln} Y_{t}-\operatorname{Ln} Y_{t}^{f}=\operatorname{Ln} A_{0}+\operatorname{Ln}\left[\delta^{-1}\left(I_{t}-K_{t-1}\right) K_{t}^{-1}\right]^{\alpha}+\operatorname{Ln}\left[\left(W / P_{0}\right) / W / P_{1}\right]^{\beta}+\operatorname{Ln} Z_{t} \\
& \operatorname{Ln} Y_{t}-\operatorname{Ln} Y_{t}^{f}=\operatorname{Ln} A_{0}+a\left[\operatorname{Ln}\left(\delta^{-1}\left(I_{t}-K_{t-1}\right) K_{t}^{-1}\right]+\beta \operatorname{Ln}\left[\left(W / P_{0}\right) /\left(W / P_{1}\right)\right]+\operatorname{Ln} Z_{t}\right.
\end{aligned}
$$

In this framework, output gap defined as capacity utilization rate occurs as a result of the current investment level of a firm, the previous accumulated capital stock and the real wage rate influenced by the general price level in the economy. Their impact on firm output gap or capacity utilization rate is transmitted through factors specific elasticities. This framework assumes that, the output observed in any time period is the equilibrium level for observed rate of utilization of the inputs (Klein and Preston, 1967). Hence, other exogenous variables that affect capacity utilization can also be conceptualized in the same manner.

\section{MATERIALS AND METHODS}

\section{Study area}

The study was conducted in Nigeria; the country is situated on the Gulf of Guinea in sub Saharan Africa. It lies between $4^{\circ}$ and $14^{\circ}$ north of the equator and between longitude $3^{\circ}$ and $15^{\circ}$ east of the Greenwich meridian. Nigeria has a total land area of $923,768.622$ $\mathrm{km}^{2}$ or about 98.3 million hectares and a population of over 140 million (NPC, 2006). Industrial sugarcane is cultivated in commercial quantities in the northern part of Nigeria, and is mostly cultivated in irrigated lands or swampy areas. Niger state, Kwara state, and Adamawa state are the major industrial sugarcane producers in the country (Lafiagi, 1984). There are 4 major sugar producing firms and two sugar refineries in Nigeria.

These are: Nigeria Sugar Company at Bacita, Kwara State established in 1964 with initial installed capacity of 40,000 tons/annum; Savannah Sugar Company Limited at Numan, Adamawa State established in 1980 with initial installed capacity of 65,000 tons/annum; Lafiaji Sugar Company in Kwara State and Sunti Sugar Company in Niger State. The last 2 are mini sugar plants.

The refineries are BUA and Dangote located in Lagos state. The refineries are not involved in direct production, but refine imported semi processed sugar from Brazil and other sugar producing countries (NSDC, 2010).

\section{Data source}

Data used in the study were purposely collected from the two sugar producing firms in Nigeria. These firms depend fully on the domestic industrial sugarcane for the production of sugar and produced more than $95 \%$ of domestic produced sugar in the country (NSDC, 2010). Also, macro economic data published by the Central Bank of Nigeria (CBN), National Bureau of Statistics (NBS), Federal Ministries of Finance, Agriculture and Rural Development as well as labour and Productivity were used in the analysis. The sugar firms selected were: Bacita Sugar Company in Kwara state and Savanna Sugar Company in Adamawa state. The data collected covered the period of 1970 to 2010.

\section{Analytical techniques}

Estimation of economic efficiency (EE), economic efficiency capacity utilization rate (EECUR) and economic capacity utilization rate (ECUR)

Economic efficiency (EE) was estimated from Equation 13

$$
E E=\frac{T V C_{j}^{*}}{T V C_{j}}=\frac{\left(P_{j}, Q_{j}, Z_{j}, \beta\right) \exp \left(V_{j}\right)}{\left(P_{j}, Q_{j}, Z_{j}, \beta\right) \exp \left(V_{j}-U_{j}\right)}=\frac{1}{\exp \left(-U_{j}\right)^{*}}
$$

Where, TVC $_{j}$ is the actual total variable cost of production, TVC $^{*}$ is the frontier total variable cost, $\mathrm{P}_{\mathrm{i}}$ represents the prices of all inputs of ith firm, $Q_{i}$ is the output level, and $Z_{j}$ represents other variables. The economic efficiency (EE) of the sugar industry presented in Equation (13) was estimated using Equation (14) specify in loglinear as follows:

$$
\begin{aligned}
& L n T V C_{t}=\delta_{0}+\delta_{1} L n W N P_{t}+\delta_{2} L n P L P_{t}+ \\
& \delta_{3} \operatorname{LnRPK}_{t}+\delta_{4} \operatorname{LnWPW_{t}}+\delta_{5} \operatorname{LnPS}_{\mathrm{t}}+\delta_{6} \operatorname{LnEC_{t}}+ \\
& \delta_{7} \operatorname{LnPOI}+\delta_{0} L n S O I_{t}+\delta_{9} L n T E P_{t}+V_{j}-U_{j}
\end{aligned}
$$

Where; $T V C_{t}=$ annual total variable cost of the sugar industry ( $\left.\mathbb{A}\right)$ $W N P_{t}=$ average wage rate of non-production workers (A) $\left(\delta T V C_{t} / \delta W N P_{t}<0\right) ; P L P_{t}=$ price of land used for sugarcane production (A) $\left(\delta T V C_{\mathrm{t}} / \delta P L P_{\mathrm{t}}>0\right) ; R P K_{t}=$ real depreciation cost

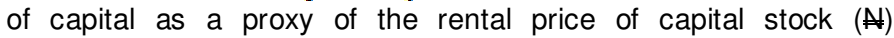
$\left(\delta T V C_{t} / \delta R P K_{t}>0\right) ; W P W_{t}=$ average annual wage rate of production worker (A) $\left(\delta T V C_{t} / \delta W P W_{t}>0\right) ; P S_{t}=$ average annual price of sugarcane ( $\mathrm{A} /$ tonne) $\left(\delta T V C_{\tau} / \delta P S_{\tau}>0\right) ; E C_{t}=$ real energy consumption, proxies by annual expenditure on energy $(\mathbb{A})$ $\left(\delta T V C_{t} / \delta E C_{t}>0\right) ; P O I_{t}=$ average price of other inputs $(\mathbb{A})$ $\left(S T V C_{i} / S P O I_{t}>0\right) ; S O_{t}=$ sugar output (tonnes) $\left(\delta T V C_{t} / \delta S O_{t}>0\right) ; T E P_{t}=$ technological progress captured by time trend $\left(\delta T V C_{t} / O T E P_{t}>0\right)$

The economic efficiency capacity utilization (EECU) was measured by using only quasi-fixed inputs in the cost functions of Equation (15) as shown in Equation (16). 
Table 4. Maximum estimates of Cobb-Douglas stochastic cost function for the sugar industry in Nigeria as defined in equation (14) and (16).

\begin{tabular}{lcc}
\hline Variable & $\begin{array}{c}\text { Equation for EE indices } \\
\text { (Equation 14) }\end{array}$ & $\begin{array}{c}\text { Equation for EECUR indices } \\
\text { (Equation 16) }\end{array}$ \\
\hline Constant & $-0.1882(-0.0932)$ & $0.5235(-1.7623)^{\star}$ \\
Wage rate of non prod. workers $\left(\mathrm{WNP}_{\mathrm{t}}\right)$ & $-0.2685(-0.3839)$ & $0.2612(0.4174)$ \\
Land price $(\mathrm{PLP})$ & $-0.1278(-1.8235)^{*}$ & $-0.2586(-2.1612)^{\star *}$ \\
Depreciation cost $\left(\mathrm{RPK}_{\mathrm{t}}\right)$ & $0.5039(3.6650)^{\star * *}$ & $0.4902(3.2466)^{\star * *}$ \\
Sugar output $\left(\mathrm{SO}_{\mathrm{t}}\right)$ & $0.9259(0.7854)$ & - \\
Wage rate of prod. worker $\left(\mathrm{WPW}_{\mathrm{t}}\right)$ & $0.7709(2.0479)^{* *}$ & - \\
Price of sugarcane $\left(\mathrm{PS}_{\mathrm{t}}\right)$ & $0.9154(0.2374)$ & - \\
Expenditure on electricity $\left(\mathrm{EC}_{\mathrm{t}}\right)$ & $-0.3379(-0.5446)$ & - \\
Price of other inputs $\left(\mathrm{POI}_{\mathrm{t}}\right)$ & $0.1614(2.1173)^{\star *}$ & - \\
Technology progress $\left(\mathrm{TEP}_{\mathrm{t}}\right)$ & $0.4417(0.5260)$ & $0.5123(0.4565)$ \\
Sigma square gamma $\left(\delta^{2}\right)$ & $0.5351(2.4249)^{\star *}$ & $0.8435(4.5056)^{* * *}$ \\
Gamma $(\lambda)$ & $0.4171(1.4150)$ & $0.6529(3.7246)^{* * *}$ \\
Log-Likelihood & -0.4425 & -0.4826 \\
LR Test & 15.4047 & 25.4047 \\
\hline
\end{tabular}

${ }^{*},{ }^{* *}$ and ${ }^{* * *}, 5,10$ and $1 \%$ significant levels respectively. Figures in brackets are t-values, and variables are as defined in Equations (14) and (16).

EECUR $=\frac{T V C_{j}^{*}}{T V C_{j}}=\frac{f\left(X_{j}^{*} ; \beta\right) \exp \left(V_{j}\right)}{f\left(X_{j}^{*} ; \beta\right) \exp \left(V_{j}-U_{j}\right)}=\frac{1}{\exp (-U)^{* *}}$

To estimate economic efficiency capacity utilization (EECUR) presented in Equation (15), we specify Equation (16) in log-linear form as follows:

$$
L n T V C_{t}=a_{0}+\alpha_{1} \operatorname{LnWNP_{t}}+\alpha_{2} \operatorname{LnPLP}_{t}+\alpha_{3} \operatorname{LnTEP_{t}}+V_{j}+U_{j}
$$

The variables have the same meaning as in Equations (13). An unbiased estimate of economic capacity rate (ECUR) was estimated using the results of Equations (14) and (16), as follows:

$E C U R=\frac{E E C U R}{E E}$

Where;

$$
\begin{aligned}
& \text { CUR } R_{t}=\gamma_{0}+\gamma_{1} I_{N F L_{t}}+\gamma_{2} \text { PDSC }_{t}+\gamma_{3} L A P_{t}+\gamma_{4} R R_{t}+\gamma_{5} P G D P_{t}+\gamma_{6} E C_{t}+\gamma_{7} L O A_{t} \\
& +\gamma_{8} S I M_{t}+\gamma_{g} F C A_{t}+\gamma_{10} D S C_{t}+\gamma_{11} D+U_{t}
\end{aligned}
$$

CUR $_{E}=$ Economic capacity utilization rate (ECUR) for the sugar industry in Nigeria; $\mathrm{INFL}_{\mathrm{t}}=$ inflation rate at period $\mathrm{t}(\%) ; \mathrm{PDSC}_{\mathrm{t}}=$

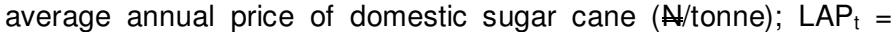
labour productivity in the sugar industry [defined as total domestic output divided by total number of workers in the sugar industry (tonnes/person)]; $\mathrm{RER}_{\mathrm{t}}=$ real exchange rate $(\mathbb{N} / \$) ; \mathrm{PGDP}_{\mathrm{t}}=$ per capita real GDP $(2003=100)(\$) ; E C_{t}=$ energy consumption proxy by annual expenditure on energy $(\$) ; L^{2 O A_{t}}=$ real loans and advances to sugar industry (A); SIMPt/GDP $\mathrm{H}_{\mathrm{t}}=$ ratio of sugar import to the GDP (\%); $\mathrm{FCA}_{t}=$ share of Federal Government Capital expenditure on the sugar industry in the GDP; $D C_{t}=$ domestic produced sugarcane used as input in the industry (tons); $\mathrm{D}=$ dummy variable which takes the value of 1 for the liberalization period (1986-2010), and 0 for otherwise (1970- 1985); $U_{t}=$ stochastic error term.

\section{RESULTS AND DISCUSSION}

\section{Estimation of economic capacity utilization (ECUR) equations for the sugar industry in Nigeria}

Maximum likelihood estimates of the Cobb-Douglas stochastic cost function for the sugar industry are presented in Table 4. The Cobb-Douglas stochastic cost function in Equation (14) was defined for all the factors of production and was used to generate indices of cost or economic efficiency. Equation (16) was defined for only input considered quasi-fixed inputs and was used to generate economic efficiency capacity utilization indices for the sugar industry. The result revealed a signific sigma squared coefficients of 0.5351 at $5 \%$ level of probability for Equation (14) and 0.8435 at $1 \%$ level of probability for Equation (16). These indicate good fit and correctness of the specified distribution assumption of the composite error term for the models. The variance ratios $(\lambda)$ in Equation (14) and (16) indicate the proportion of variations in the total variable cost in the sugar industry in Nigeria that is due to deviation from full economic efficiencies and economic capacity utilization respectively. In Equation (16), a gamma ratio of 0.4171 suggests that the presence of economic or cost inefficiency in the sugar industry in Nigeria explained about $41.71 \%$ variations in the total variable cost of the industry. In the same way, the gamma ratio of 0.6529 for Equation (16) implies that about $65.29 \%$ of variations in the total variable cost are 


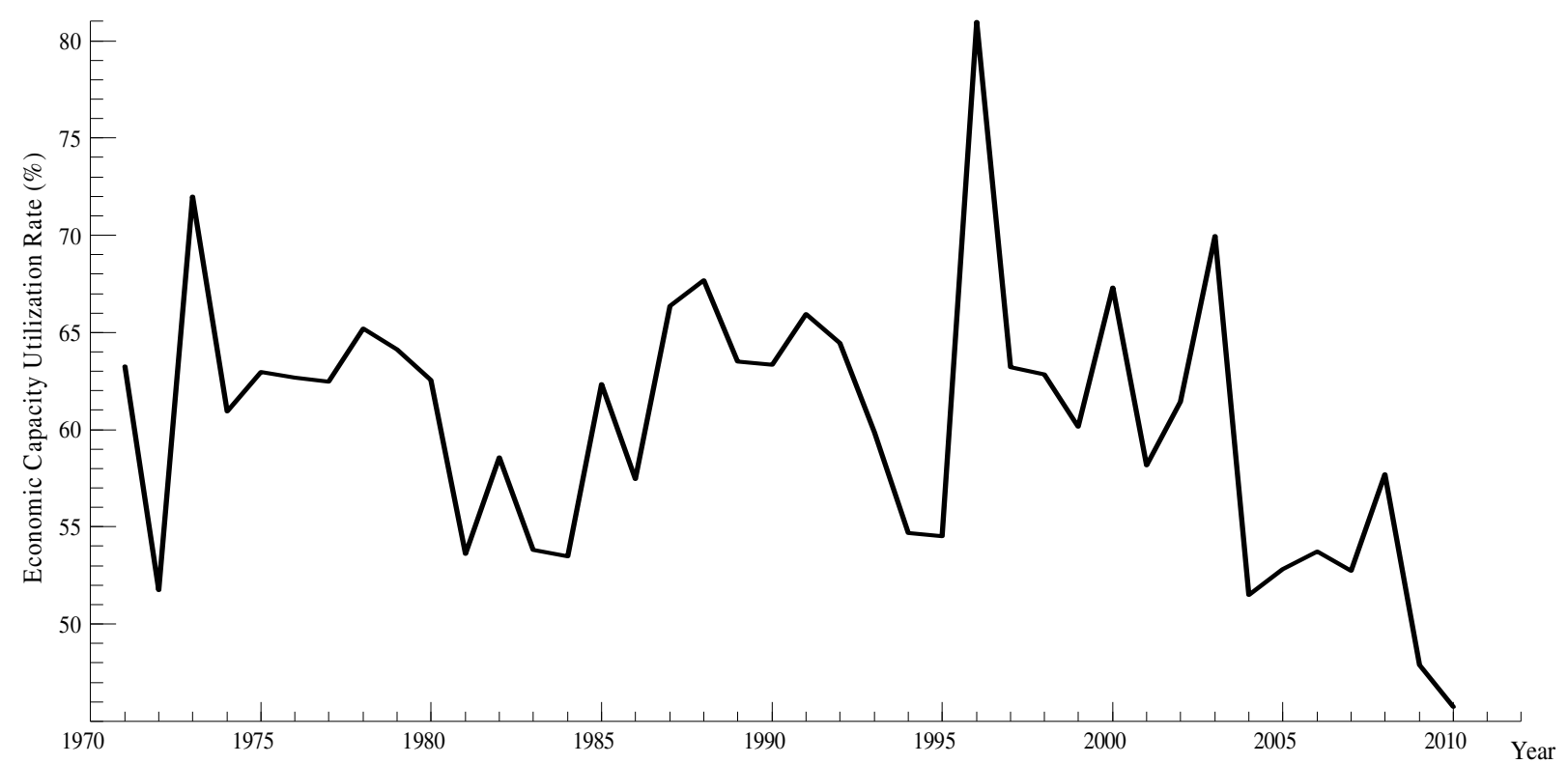

Figure 1. Trend in economic capacity utilization rates in the sugar industry in Nigeria.

attributed to cost inefficiency and unutilized cost capacity. The generalized likelihood ratio tests for the equations are highly significant and this confirms the presence of one - sided error component in the composite error terms. Therefore, the result of the diagnostic test confirmed the relevance of the stochastic parametric cost function and maximum likelihood estimation technique.

The empirical results reveal that land price $\left(P L P_{t}\right)$, depreciation cost $\left(\mathrm{RPK}_{\mathrm{t}}\right)$, wage rate of production workers $\left(\mathrm{WPW}_{\mathrm{t}}\right)$, and price of other inputs $\left(\mathrm{POI}_{\mathrm{t}}\right)$ were significant production variables that affect the value of total variable cost in the sugar industry in Nigeria.

\section{Trend in the estimated economic capacity utilization rates in the Nigerian sugar industry}

The trend in the estimated economic capacity utilization in the sugar industry is shown in Figure 1. The trend displayed highly undulated pattern throughout the considered years. In all observations, economic capacity utilization rate (ECUR) was less than unity with an average value of $60.30 \%$; implying that the industry had an excess economic capacity utilization of about $39.70 \%$. This means that the industry needed about $39.70 \%$ economic capacity gain to reach the economic or optimum capacity frontier. The present of the excess economic capacity utilization in the industry implies that the industry suffered from insufficient fund needed to cover the cost of production. This means that the industry was constrained by insufficient financial resources which prevented the attainment of the optimum economic capacity utilization level.

\section{Determinants of economic capacity utilization rates of the Nigerian sugar industry}

Table 5 reports the result of estimation of the economic capacity utilization equations in sugar industry in Nigeria. The linear form of the specified equations was picked as the lead equation following the result of the diagnostic tests and the number of significant independent variables. For the lead equation, $R^{2}$ is 0.848 denoting that about $84.80 \%$ of variations in economic capacity utilization rate were explained by the specified independent variables. The F-statistic of 3.088 is significant at $1 \%$ probability level, implying that the $\mathrm{R}^{2}$ is significant and the model has goodness of fit. Durbin- Watson statistic of 2.74 indicates that auto-correlation might pose a minor problem. The empirical result revealed that the coefficient of inflation rate $\left(\mathrm{INFL}_{\mathrm{t}}\right.$ ) is statistically significant (at $10 \%$ level) and negatively related to the economic capacity utilization rates in the sugar industry. This relationship indicates that an increase in the inflation rate will lead to a decrease in economic capacity utilization rates in the sugar industry. For instance, $10 \%$ increase in inflation rate will result in $0.01 \%$ decrease in economic capacity utilization rate. A similar result has been reported for the manufacturing sector in Nigeria by Ukoha (2000). However, the result is contrary to the findings of McElthattan (1985), Franz and Gordon (1993), Garner (1994) and Yoo (1995) in the United State of America.

The result also revealed a significant positive (at 5\% level) relationship between the per capita real GDP $\left(P G_{t}\right)$ and economic capacity utilization rate in sugar industry in Nigeria. The result is in line with the economic theory, because an increase in per capita real GDP 
Table 5. Economic capacity utilization rate equations in sugar industry in Nigeria

\begin{tabular}{|c|c|c|c|c|}
\hline Variable & Linear (L) & Exponential & Semi-log & Double- log \\
\hline Constant & $0.703(5.60)^{\star \star \star}$ & $-0.321(-1.61)$ & $0.515(1.37)$ & $-0.639(-1.05)$ \\
\hline $\mathrm{INFL}_{t}$ & $-0.001(-1.98)^{\star}$ & $-0.002(-2.16)^{\star \star}$ & $-0.003(-0.23)$ & $-0.009(-0.35)$ \\
\hline $\mathrm{PDSC}_{\mathrm{t}}$ & $-9.20 \mathrm{e}-008(-0.03)$ & $-3.69 \mathrm{e}-007(-0.09)$ & $-0.032(-0.79)$ & $-0.063(-0.95)$ \\
\hline $\mathrm{LAP}_{\mathrm{t}}$ & $-0.005(-0.69)$ & $-0.009(-0.83)$ & $-0.032(-0.18)$ & $-0.068(-0.24)$ \\
\hline $\mathrm{RER}_{\mathrm{t}}$ & $-1.73 e-005(-0.02)$ & $-5.92 e-005(-0.05)$ & $0.0006(0.02)$ & $0.003(0.07)$ \\
\hline $\mathrm{PGDP}_{\mathrm{t}}$ & $6.85 \mathrm{e}-005(2.64)^{* \star}$ & $0.0001(2.79)^{* *}$ & $0.009(0.32)$ & $0.008(0.15)$ \\
\hline$E C_{t}$ & & $-0.0002(-1.67)^{*}$ & $-0.020(-1.56)$ & $-0.040(-1.75)^{\star}$ \\
\hline$L^{\prime} O A_{t}$ & $-0.0001(-1.89)^{*}$ & $5.19 \mathrm{e}-006(1.56)$ & $0.003(0.88)$ & $0.005(0.91)$ \\
\hline $\mathrm{SIMP}_{\mathrm{t}} / \mathrm{GDP}_{\mathrm{t}}$ & $3.07 e-006(1.46)$ & $-0.161(-0.89)$ & $-0.010(-0.67)$ & $-0.016(-0.66)$ \\
\hline $\mathrm{FCA}_{\mathrm{t}}$ & $-0.086(-0.76)$ & $8.77 e-005(2.21)^{\star \star}$ & $-0.011(2.33)^{\star \star}$ & $0.017(2.27)^{\star *}$ \\
\hline $\mathrm{DSC}_{\mathrm{t}}$ & $5.38 \mathrm{e}-005(2.14)^{\star *}$ & & $0.031(0.75)$ & $0.056(0.83)$ \\
\hline Policy dummy & $\begin{array}{c}1.81 \mathrm{e}-007(1.03) \\
0.213(2.93)^{\star \star \star}\end{array}$ & $\begin{array}{c}3.21 \mathrm{e}-007(1.15) \\
0.353(3.07)^{\star * \star}\end{array}$ & $0.179(2.71)^{* *}$ & $0.302(2.80)^{* *}$ \\
\hline $\mathrm{R}^{2}$ & 0.848 & 0.819 & 0.417 & 0.442 \\
\hline F-Statistic & $3.088^{* * *}$ & $3.647^{\star \star \star}$ & $1.822^{*}$ & $2.0215^{\star}$ \\
\hline DW-test & 2.74 & 2.73 & 2.25 & 2.17 \\
\hline Normality test & $7.957(0.0187)^{\star \star}$ & $4.297(0.1166)$ & $7.872(0.0195)^{*}$ & $5.321(0.0699)^{*}$ \\
\hline Hetero-test & $0.336(0.9709)$ & $0.369(0.9586)$ & $0.102(1.0000)$ & $0.112(0.9999)$ \\
\hline RESET -test & $7.836(0.001)^{\star \star \star}$ & $6.383(0.004)^{\star \star \star \star}$ & $2.462(0.1280)$ & $5.027(0.0334)^{\star *}$ \\
\hline Schwarz Criterion & -89.04 & & -78.56 & -40.14 \\
\hline Akaike Criterion & -109.98 & -52.38 & -99.13 & -60.41 \\
\hline Hannan- Quinn C. & -101.98 & -72.64 & -91.80 & -53.08 \\
\hline loglikelihood & 66.65 & $\begin{array}{c}-65.32 \\
48.32\end{array}$ & 61.57 & 42.21 \\
\hline
\end{tabular}

${ }^{*},{ }^{* *}$ and ${ }^{* * *}, 10,5$ and $1 \%$ significance levels respectively. Figures in bracket are t-values and variables are as defined in equation (18). $L$ means lead equation.

raises the demand level of consumers in the economy. Increased in the per capita real GDP would exert positive influence on the industry's net returns. This has a tendency to boost the economic capacity of the industry through increase ability to procure more production inputs. The result implies that the sugar industry in Nigeria was not demand constrained. Ukoha (2000) obtained a similar result for the Nigeria's manufacturing sector. The expenditures on energy in the sugar industry in Nigeria had a significant negative effect (at $10 \%$ level) on the economic capacity utilization rate of the industry. The result implies that increase in energy consumption decreases economic capacity utilization rate of the industry. The finding agrees to the a priori expectation as increase in energy consumption will tend to increase the total variable cost of the industry. This has an adverse effect on the net returns of the industry and the economic capacity utilization rates.

The coefficient of the federal government capital expenditure on sugar industry $\left(F C A_{t}\right)$ was significant (at $5 \%$ level) and was a positive determinant of economic capacity utilization rate in the sugar industry. The result implies that, as the federal government subventions to the sugar industry increase the economic capacity utilization rates of the industry also increase. For instance, one million naira increase in the federal government subvention to the sub-sector will result in $0.000054 \%$ gains in economic capacity utilization rate in the industry. The reason for the result might be attributed to the fact that the sub-sector was completely owned by the federal government before it was privatized.

The liberalization policy period (D) had a significant positive influence on the economic capacity utilization in the sugar industry. This implies that the industrial policies embedded in the liberalization period had significant positive influence on the economic capacity utilization rate in sugar industry. The result agrees with the findings of Gokcekus, (1997) in Turkey, Earl and Amos (2002) in Romania, Phillipe and Robin (2003) in UK and Akpan et al., (2012a) in Nigeria.

\section{CONCLUSION AND RECOMMENDATIONS}

The study used sugar industry based data and macroeconomic data from 1970 to 2010 to analyze economic 
capacity utilization rates in the sugar industry in Nigeria. Sugar industry based data collected were production and cost data. The macro-economic data used were inflation rate, exchange rate, GDP, tariff rates on sugar import, consumer price index, parallel and official exchange rates among others. Unit root tests were conducted on the specified variables in economic capacity utilization equation and their stationary determined. Similarly, the specified cost function variables for the industry were used at their levels to estimate the economic capacity utilization indices and economic efficiency indices from which the unbiased economic capacity utilization rates in the sugar industry were calculated. Multiple-regression equation of various forms was estimated based on the ordinary least squares method and used to determine factors that influence the economic capacity utilization rate.

Also, the patterns of fluctuations in the estimated economic capacity utilization rate in the industry showed undulated trend throughout the study period with an average value of $60.30 \%$ and excess capacity of about $39.70 \%$. The finding also revealed that the economic capacity utilization rate in the industry had significant positive association with per capita real GDP, share of federal government expenditure on sugar industry in the GDP and liberalization policy period. The inflation rate and energy consumption had significant negative relationship with the industry economic capacity utilization rates.

To improve economic capacity utilization rate in the sugar industry in Nigeria, the study advocated for a policy package that either reduces or maintains a steady inflation rate in the country as this will enhance increase capacity utilization in the sugar industry in Nigeria. It is also recommended that an appropriate policy measure that aim at expansionary aggregate demand as a means of promoting capacity utilization in the sugar industry should be introduced. Such policy measure should be designed to avoid inflationary tendencies. Government should strengthen the power sector to provide constant electricity to sugar industry in Nigeria. This will help to lower the total variable cost of the industry and increase the net returns as well as the capacity utilization of the industry. Furthermore, the industrial policy package during liberalization era will promote economic capacity in the industry.

\section{REFERENCES}

Adeel M, Teal F, Simon B (2004). The Performance of Nigerian Manufacturing Firms. Report on the Nigeria Manufacturing Enterprise Survey.

African Development Bank (ADB) (2000). Operations Evaluation documents.

African Development Fund (ADF) (2000) Operations Evaluation documents.

Akpan SB, Udo UJ, Essien UA, (2011). Influence of Firm related factors and Industrial Policy Regimes on Technology Based Capacity Utilization Rate in Sugar Industry in Nigeria. Agric on-line Papers in
Economics and Informatics. III, 3:15-22.

Akpan SB, Obasi O, Ukoha CE. Onyenweaku-Daniel EJ (2012a). Empirical Relationship among Technical Efficiency, Macroeconomic Variables and Industrial policy Regimes: A case study of Sugar Industry in Nigeria. Int. J. Econ. Manag. Sci. 1(10):01-11.

Akpan SB, Ini-mfon VP, Daniel EJ (2012b). Impact of macro-economic variable fluctuations on technology based capacity utilization in sugar industry in Nigeria. Int. J. Econ. Manag. Sci. 1(11):26-34.

Anyanwu JC, Oyefusi A, Oaikhenan H, Dimowo FA (1997). The Structure of the Nigerian Economy (1960-1997). Onitsha Joanee Educational Publisher.

Ayayi DD (1988). Spatial Patterns of Production Sub-contracting in Nigeria. Nig. J. Econ. Soc. Stud. (NSESS), 42(1):95-111.

Ayeni B (1981). The Spatial Distribution of Manufacturing Industries in Nigeria. Technical Report No. 2 Department of Geography, University of Ibadan.

Azeez EA (2002). Economic Reforms and Industrial Performance'. An Analysis of Capacity Utilization in Indian manufacturing Sector. A Technical Working paper at the Institute of Economic Growth, Delhi India.

Barik K (2000). Capacity utilization in Indian paper industry, Publication of the School of Social Science, India Gandhi National Open University, New Delhi.

Berndt E, Hesse D (1986). Measuring and Assessing Capacity Utilization in the Manufacturing Sectors of Nine OECD Countries. Europ. Econ. Rev. 30:961-989.

Berndt ER, Morrison CJ (1981). Capacity Utilization: Underlying Economic Theory and Alternative Approach. Am Econ. Rev. 71:4852.

Busari LD, Misari SM (1996). Sugar and sugarcane in Nigeria. A Publication of NCRI in Nigeria.

Cassels JM (1937). Excess Capacity and Monopolistic Competition. Q. J. Econ. 51:424-443.

Central Bank of Nigeria (CBN), Statistical Bulletin, (2006, 2008, 2009).

Danish AH (2003). Capacity Utilization in Indian Airlines. A Postdoctoral Fellowship Study at the Institute of Economic Growth, Delhi, India.

Dunlevy J (1980). Aggregate Stocks and the Relationship between United State's Business Cycle Fluctuation and Export Performance. J. Econ. Integr. 13(1):163-198.

Ekeocha PC (2009). Evaluation of the effectiveness of industrial policy reforms in Nigeria 1999-2003: A computable general equilibrium simulation. Analysis presented at the 50th annual conference of the Nigerian Economic Society (NES) in Abuja September, 22-24th, 2009.

Fabayo A (1981). Production Function Measure of Capacity Output and Rate of Capacity Utilization in Selected Nigerian Industries: 19741975. Ife Social Sci. Rev. 2 (2):0-27.

FAO Corporate Document on Capacity Utilization in Fishery Sub-sector (2006).

Federal Ministry of Industry Abuja (FMI), Nigeria (2003). "National Sugar Policy". A Publication of National Sugar Development Council of Nigeria.

Franz W, Gordon RJ (1993). German and American Wage and Price Dynamics: Europ. Econ. Rev. May, pp. 719-762.

Friedman M (1963). More on Archibald versus Chicago Review of Economic Studies, 30:65-67.

Garner C, Alan (1994). Capacity Utilization and USA Inflation. Federal Reserve Bank of Kanakas City, Econ. Rev. 79(4):1-21.

Gokcekus O (1997). Trade liberalization and capacity utilization; New evidence from Turkish Rubber industry. Empir. Econ. 23;561-571.

Hashim DA. (2003). Capacity utilization in Indian airlines: A paper presented to Institute of Economic Growth., Delhi, India.

Hayes S, Stone J (1983). Specification of Supply Behaviors. Rev. Econ. Stat. 64:271-281.

Hickman BG (1964). On a new Method for Capacity Estimation. J. Am. Stat. Assoc. 59:529-549.

Isola WA (2006). Market reform and de-industrialization in Nigeria: 1986 -2003. Essays on Economic Development. MPRA paper no. 1025, 2006. http:// mpra.ub.uni-muenchen.de/ 1025/

ISYB (1978). International Sugar Year Book (1978), Publication of the Federal Ministry of Industry.

Kenny G (1996). Capacity Utilization in Irish Manufacturing Sector. 
Technical Paper Presented to Central Bank of Ireland.

Kim HY (1999). Economic capacity utilization and its determinants: theory and evidence. Rev. Indust. Organ. 15;321-339.

Kim YC, Kwon JK (1977). The Utilization of Capital and the Growth of Output in a Developing Economy: the Case of South Korean Manufacturing. J. Dev. Econ. 4:265-78.

Klein LR, Preston RS (1967). Some new results in the measurement of capacity utilization. Am. Econ. Rev. 57:34-58.

Klein LR (1960). Some Theoretical Issue in the Measurement of Capacity. Econometrica 28:272-286.

Kumar S, Nitin A. (2009). Analyzing regional variations in capacity utilization of Indian sugar industry using non- parametric frontier technique. Eurasian J. Bus. Econ. 2(4):1-26.

Lafiagi MS (1984). Towards Self-Sufficiency in Sugar Production in Nigeria. Memo Submitted to Federal Ministry of Commerce and Industry pp. 1-46.

Lecraw DJ (1978). Determinants of capacity utilization by firms in less developed countries. J. Dev. Econ. 2(2):139-153.

Manufacturing Association of Nigeria Publication (2006, 2009).

McElthattan R (1985). Inflation, Supply Stock and the Stable Inflation Rate of capacity Utilization. Federal Reserve Bank of San Francisco, Econ. Rev. Winter 1:45-63.

Michael D (2010). USDA foreign Agricultural service on sugar imports in Nigeria. A comprehensive report on sugar imports in Nigeria. http://www.nigerianseminarsandtrainings.com. Retrieved 10-12-2010.

Morrison CJ (1985). Primal and Dual Capacity Utilization, An application to Productivity Measurement in the USA Automobile Industry. J. Bus. Econ. Statis. 3:312-324.

National Population Commission (NPC) (2006). National Census Data. www.population.gov.ng/. Retrieved 10-12-2010.

National Sugar Company Document (NISUCO) (1999). A Publication of National Sugar Development Council, Federal Ministry of Industry, Abuja, Nigeria.

National Sugar Development Council Document (NSDC) (2006, 2010 and 2012). A Publication of National Sugar Development Council, Federal Ministry of Industry, Abuja, Nigeria. http://www.nsdc.gov.ng/

Nigerian Sugar Company Ltd., Bacita Estate (NISUCO) (2000). Production Statistic for each Agricultural Year from 1965 to 2000.

Nwaobi GC (2005). The Nigerian sugar industry (1960-1987). 0501001, EconsWPA.
Ogunbayo M (2009). The fall of the Giant Unpublished Paper. Extracted from internet, (http://www.newswatch.ngr.com, 10-01-2011)

Olomola AS (2007). Competitive commercial Agriculture in Africa study (CCAA), Nigeria case study. A final report submitted to the Canadian International Development agency (CIDA) and the World Bank.

Prior D, Nela F (2001). On the Measurement of Capacity Utilization and Cost Efficiency: A Non- Parametric Approach at Firm Level. Pesquisa Operational 22(2):247-263.

Raimi L, Adeleke I (2009). A Review and Measurement of Capacity Utilization in the Nigerian Economy. Humanomics 25(4):274-284.

Salimonu KK, Gafar OA, Akintola JO (2006). Trend Analysis of Capacity Utilization of Agro-based Industries in Nigeria. Agric. J. 1(4):311-314.

Savannah Sugar Company limited (SSC) (2006) 2010. Production Data for Savannah Sugar Company Ltd., Numan, 1983-1999. The Punch Newspaper, Thursday Sept. 14, 2000, P. 23.

Seth K (1998). Economic Reforms and Capacity Utilization in Indian Industry", Productivity 39(3):391-98.

Soderbom M, Teal F (2002). The Performance of Nigerian Manufacturing Firms. Report on the Nigerian Manufacturing Enterprise Survey 2001.

World Bank (2001), Nigeria: poverty in the Midst of Plenty, The Challenge of Growth with Inclusion.

Ukoha OO (2000). Determinants of Manufacturing Capacity Utilization in Nigeria, 1970-1988. Nig. J. Econ. Soc. Stud. 42(2):121-129.

Wada AC, Agidi G, Ishaq MN, Busari LD (2001). Current Status of Sugar Research and Development in Nigeria. Sugar Technol. 3(1):412.

Yoo PS (1995). Capacity Utilization and Price within Industries, Federal Reserve Bank of St. Louis Review 77(5). Sept. - Oct. 15-25.

Zayyad HR (2007). Privatization and Commercialization in Nigeria. Unpublished Work in the Internet (http://unpanl.un.org/intradoc/groups/public/docume. 15-10-2010). 